\title{
Electrochemical Investigation of the Synergistic Effect Between Molybdate and Tungstate on Surface Passivation of Carbon Steel
}

\author{
Pei Zhang ${ }^{1, *}$, Yijiang Chen ${ }^{2}$,Yong Zhou ${ }^{2, * *}$, Fuan Yan $^{2}$, Guochao Nie ${ }^{3}$ \\ ${ }^{1}$ College of Chemical and Food Science, Yulin Normal University, Yulin 537000, China \\ ${ }^{2}$ Key Laboratory for Green Chemical Process of Ministry of Education, Wuhan Institute of Technology, \\ Wuhan 430205, China \\ ${ }^{3}$ College of Physics and Telecommunication, Yulin Normal University, Yulin 537000, China \\ *E-mail: zhang200622072@163.com \\ **E-mail: zhouyong@wit.edu.cn
}

doi: $10.20964 / 2021.01 .49$

Received: 1 October 2020 / Accepted: 9 November 2020 / Published: 30 November 2020

The purpose of this paper was to understand the synergistic effect between molybdate and tungstate for the surface passivation of carbon steel, particularly to find the optimum ratio of molybdate and tungstate. For Q235 carbon steel in mixed $\mathrm{Na}_{2} \mathrm{MoO}_{4}$ and $\mathrm{Na}_{2} \mathrm{WO}_{4}$ solutions with different ratios of $\mathrm{MoO}_{4}{ }^{2-}$ and $\mathrm{WO}_{4}{ }^{2-}$, the electrochemical methods, including potentiodynamic polarization, MottSchottky and electrochemical impedance spectroscopy (EIS), were applied. Under the total concentration of $0.2 \mathrm{mmol} / \mathrm{L}$, the ratio variation of $\mathrm{MoO}_{4}{ }^{2-}$ and $\mathrm{WO}_{4}{ }^{2-}$ did not affect the corrosion behavior of Q235 carbon steel, and the main corrosion parameters, including corrosion potential $\left(\mathrm{E}_{\mathrm{c}}\right)$, corrosion current density $\left(\mathrm{i}_{\mathrm{c}}\right)$, flat band potential $\left(\mathrm{U}_{\mathrm{f}}\right)$ and inner-layer passive film resistance $\left(\mathrm{R}_{\mathrm{i}}\right)$ were independent of the ratio variation; however, the ratio variation of $\mathrm{MoO}_{4}{ }^{2-}$ and $\mathrm{WO}_{4}{ }^{2-}$ affected the passivation behavior of Q235 carbon steel obviously, and the main passivation parameters, including transpassive potential $\left(\mathrm{E}_{\mathrm{t}}\right)$, donor density $\left(\mathrm{N}_{\mathrm{D}}\right)$ and outer-layer passive film resistance $\left(\mathrm{R}_{\mathrm{o}}\right)$, presented the optimum level when the ratio of $\mathrm{MoO}_{4}{ }^{2-}$ and $\mathrm{WO}_{4}{ }^{2-}$ was one to one. At the same time, the related mechanisms of corrosion and passivation were also discussed.

Keywords: carbon steel; molybdate $\left(\mathrm{MoO}_{4}{ }^{2-}\right)$; tungstate $\left(\mathrm{WO}_{4}{ }^{2-}\right)$; surface passivation; synergistic effect; electrochemistry

\section{$\underline{\text { FULL TEXT }}$}

(C) 2021 The Authors. Published by ESG (www.electrochemsci.org). This article is an open access article distributed under the terms and conditions of the Creative Commons Attribution license (http://creativecommons.org/licenses/by/4.0/). 